Çakmakcı, C. C. ve Demir, N. (2021). Okul deneyimi ve öğretmenlik uygulaması dersleri açısından Türkiye ve Finlandiya'da ana dili öğretmeni yetiştirme süreci. Ana Dili Eğitimi Dergisi, 9(4), 1169-1187.

Ana Dili Eğitimi Dergisi
Journal of Mother Tongue Education
www.anadiliegitimi.com
Geliş/Received: 01.06 .2021 Kabul/Accepted: 16.07 .2021
Araştırma Makalesi / Research Paper

\title{
“Okul Deneyimi” ve “Öğretmenlik Uygulaması” Dersleri Açısından Türkiye ve Finlandiya'da Ana Dili Öğretmeni Yetiştirme Süreci*
}

\author{
Celal Can ÇAKMAKCI** \\ Necati DEMiR ${ }^{* * *}$
}

\begin{abstract}
Öz
Öğretmen adaylarının hizmet öncesi eğitimlerinde aldıkları teorik dersler kadar mesleki deneyim kazandırmaya yönelik derslerin de önemi vardır. Ortaokullar için Türkçe öğretmeni yetiştiren programlarda söz konusu dersler okul deneyimine ve öğretmenlik uygulamalarına dayanmaktadır. Bu çalışmanın amacı, dünyada eğitim alanında "model" olarak kabul edilen ülkelerin başında gelen Finlandiya'da ana dili öğretmeni yetiştiren yükseköğretim programlarında uygulanmakta olan okul deneyimi ve öğretmenlik uygulaması derslerinin Türkçe eğitimi programlarındakiler ile karşılaştırılmasıdır. Bu noktadan hareketle, Türkiye'de ana dili öğretmeni yetiştirme programlarının içeriğinde düzenlemeler yapılırken istifade edilebilecek somut öneriler getirilebilecektir. Bu araştırma nitel durum çalışması olarak planlanmıştır. Araştırmanın veri kaynağını Türkiye ve Finlandiya'daki ana dili öğretmeni yetiştirme programları oluşturduğu için araştırmada doküman analizi yöntemi kullanılmıştır. Araştırmanın alt problemlerinden hareketle karşılaştırmalı olarak veriler düzenlenmiştir. Sonrasında verilerin benzerlik ve farklılıkları tespit edilmiştir. İstatistiksel işlem olarak yüzde hesaplamaları kullanılmıştır. Araştırmanın en dikkat çeken sonucu, Fince öğretmeni yetiştirme sürecindeki staj derslerinin Türkçe öğretmeni yetiştiren programlardakilere nazaran müfredat içerisinde daha ağırlıklı olarak yer aldığının tespitidir. Bu doğrultuda, araştırmada mesleki deneyim kazandıran derslerin programdaki payının arttırılması için Türkçe öğretmeni adaylarının hizmet öncesi eğitim sürecinin uzatılması gerektiği önerilmiştir. Öte yandan, Türkiye'de yaşanan uygulama okulu bulma konusundaki zorlukların aşılabilmesi için eğitim fakültelerine bağlı olarak hizmet veren uygulama okullarının kurulması önemli ölçüde fayda sağlayacaktır.
\end{abstract}

Anahtar kelimeler: Ana dili öğretmenliği, okul deneyimi, öğretmenlik uygulaması, Türkçe öğretmenliği, Fince öğretmenliği

\section{Mother Tongue Teacher Training Process in Turkey and Finland in Terms of "School Experience" and "Teaching Practice" Courses}

\begin{abstract}
As well as the theoretical courses that teacher candidates take in their pre-service training, the courses aimed at gaining professional experience are also important. In programs that train Turkish teachers for secondary schools, these courses are based on school experience and teaching practices. The aim of this study is to compare the school experience and teaching
\end{abstract}

\footnotetext{
* Bu makale, 2017 yılında Gazi Üniversitesi Eğitim Bilimleri Enstitüsü Türkçe Eğitimi Bilim Dalında Prof. Dr. Necati Demir'in danışmanlığı ile tamamlanan “Avrupa Birliği’ne Üye Ülkelerden İngiltere, Almanya, Fransa ve Finlandiya ile Türkiye'deki Ana Dili Öğretmeni Programlarının Karşılaştırılması" isimli doktora tezinden üretilmiştir.

** Dr. Öğr. Üyesi, Zonguldak Bülent Ecevit Üniversitesi, Ereğli Eğitim Fakültesi, Türkçe ve Sosyal Bilimler Eğitimi Bölümü, Zonguldak, ccan.cakmakci@beun.edu.tr, ORCID: orcid.org/0000-0002-9959-814X

*** Prof. Dr, Gazi Üniversitesi, Gazi Eğitim Fakültesi, Türkçe ve Sosyal Bilimler Eğitimi Bölümü, Ankara, necatidemir@gazi.edu.tr, ORCID: orcid.org/0000-003-0762-410X
} 
practice courses applied in higher education programs that train mother tongue teachers in Finland, which is one of the leading countries in the field of education in the world, with those in Turkish education programs. From this point of view, concrete proposals can be made that can be utilized while making arrangements in the curriculum of mother tongue training programs in Turkey. This study was planned as a qualitative case study. Since the data source of the study is mother tongue teacher training programs in Turkey and Finland, document analysis method was used. Based on the sub-problems of the study, the data were arranged comparatively. Then the similarities and differences of the data were determined. Percentage calculations were used as statistical operations. The most striking result of the study is that internship courses in the process of training Finnish teachers are more predominantly included in the curriculum than those in the program that trains Turkish teachers. Accordingly, it is suggested that the preservice training period of Turkish teacher candidates should be extended in order to increase the share of the courses that provide professional experience in the curriculum. On the other hand, in order to overcome the difficulties in finding a practice school in Turkey, founding practice schools that serve under education faculties will provide significant benefits.

Keywords: Mother tongue teaching, school experience, teaching practicum, Turkish teacher, Finnish teacher

\section{Giriş}

Öğretmenlik, insana ve topluma şekil verebilen, kimliğiyle bütün toplumlar için önemli ve vazgeçilemez bir meslektir. Bu mesleğin icracısı olan öğretmen de "okul" adı verilen sosyal sistemin en stratejik parçalarından birisidir (Bursalıoğlu, 2012: s.42). Eğitimin en önemli unsurlarından birisi olan ve ülkelerin geleceklerini şekillendirecek olan nesilleri yetiştirme sorumluluğunu üstlenen öğretmenlerin hizmet öncesi eğitimlerinin nasıl yapılandırılması gerektiği, uzun yıllardan bu yana pek çok çalışmaya (Adıgüzel, 2008; Akar, 2003; Akdemir, 2013; Aksoy, 2013; Aykaç, Kabaran ve Bilgin, 2014; Ateş ve Burgaz, 2014; Azar,2011; Bay, 2008; Ergün, 1987; Eşme, 1998; Kavcar, 2002; Köse, 2016; Üstüner, 2004) konu olmuştur. Toplumların her geçen gün farklılaşan ve artan ihtiyaçları, ülkeler için öğretmen yetiştirme sistemlerinin düzenli olarak gözden geçirilip çağın ihtiyaçlarına göre güncellenmesini kaçınılmaz hâle getirmektedir.

Öğretmenlik eğitimi süreci alan bilgisi, genel kültür ve öğretmenlik meslek bilgisine yönelik dersler vasıtasıyla gerçekleşir. Öğretmenlik meslek bilgisine yönelik eğitim ise kuramsal dersler ve uygulamalardan oluşur. Kuramsal derslerde öğrenilen teorik bilgiler, ancak okul ortamındaki uygulamalar aracılığıyla davranışlara dönüştürülebilir.

Dünyadaki ülkelerin pek çoğunda okul deneyimi ve öğretmenlik uygulamalarının birbiriyle bağlantılı ve uyumlu olarak ilerlemesi gereken iki farklı boyutu vardır. Bunlardan ilki üniversitede sorumlu öğretim elemanlarının denetiminde yürütülen çalışmalar olarak kabul edilirken, diğeri okul ortamında gerçekleştirilen uygulamalardır. Sözü edilen bu iki boyut, öğretmen adaylarını meslek yaşantılarına hazırlamanın yanı sıra, adaylara yaşamlarının önemli bir bölümünde icra edecekleri mesleği tanıma olanağı da sağlayacaktır. Bu denli önemli işleve sahip derslerin, öğretmen eğitiminin amaçlara uygun şekilde planlanması ve yürütülmesi son derece önemlidir.

Kültür aktarma işlevi açısından bakıldığında eğitimin önemli bir ayağını ana dil eğitimi oluşturmaktadır. Ayrıca öğrencilerin kişilik kazanmalarında, zihnî ve ruhî gelişmelerinde ana dili öğretiminin rolü büyüktür (Güzel, 2003 akt. Özkan, 2014, s. 16). Bu nedenle de eğitim ve öğretimin faaliyetleri içerisinde Türkçe eğitiminin ve bu eğitimi yürütecek olan Türkçe öğretmeninin ayrıcalıklı ve önemli bir yeri vardır. Çünkü Türkçe eğitim ve öğretimi, bireyin bütün öğrenmeleri gerçekleştirirken kullanacağı anahtar olan bilgi, beceri ve donanımları kazandırır (Tosunoğlu, 2007, s. 18). Diğer branşlarda olduğu gibi Türkçe öğretmeni yetiştiren programlardaki okul deneyimi ve öğretmenlik uygulaması derslerinin de çağın ihtiyaçlara göre yapılandırılması gerekmektedir. Düzenlemelerin hayata geçirilmesinde uzmanlara ve yetkililere fikir verebilecek önemli bir unsur, "model" olarak kabul edilen ülkelerdeki sistemlere ait bulgulardır. Bu bulgular karşılaştırmalı eğitim araştırmaları vasıtasıyla elde edilebilirler (Uygun, Ergen ve Öztürk, 2011, s. 391). Söz konusu ülkelerin ilk akla gelenlerinden birisi Finlandiya'dır. Finlandiya'nın öğretmen yetiştirme dâhil olmak üzere eğitim ile ilgili konularda nadiren reform gerçekleştiren bir ülke olması uygulamaların zaman 
içerisinde değişikliğe uğramamasına neden olmuştur. 1970 yılında temelleri atılan Finlandiya eğitim sistemi aradan yaklaşık 40 yıl geçmesine rağmen temel prensiplerinden taviz vermemiştir. Bu süre zarfında 20 hükûmet, 30 eğitim bakanı değişmiş olmasına rağmen eğitim sisteminde önemli değişikliklere gidilmemiştir. Finlandiya eğitim sistemini bu kadar başarılı kılan en önemli unsur anayasa ve yasalarla güvence altına alınan istikrarlı yapının sürekli muhafaza edilmiş olmasıdır. Herkes için ve her yerde eğitim, eğitim hizmetlerinde sosyal ve bölgesel bakımdan eşitlik, hayat boyu eğitim, iyi eğitimli ebeveynler Finlandiya' da eğitim politikalarına yön veren en önemli unsurlar olarak öne çıkmaktadır (Çelik, 2016, s. 23). Bugün dünyanın en başarılı eğitim sistemlerinden birisine sahip olan Finlandiya (Şemşek, 2014, s. 24), eğitim ve öğretimdeki başarısı ile eğitim turizmi geliri elde edecek duruma gelmiştir. Her yıl dünyanın dört bir yanından araştırmacılar, ülkenin eğitim sistemi ile ilgili incelemeler yapmak için ziyaretlerde bulunmaktadırlar.

2017 yılı itibarıyla TR Dizin, DergiPark ve YÖK Tez Tarama veri tabanlarında bu çalışmanın anahtar kelimeleriyle yapılan tarama sonucunda Türkiye ve Finlandiya'da ana dili öğretmeni yetiştirme sürecinde verilen okul deneyimi ve öğretmenlik uygulaması derslerini incelemeye yönelik bir araştırma olmadığı tespit edilmiştir. Buradan hareketle araştırmanın amacı, Türkiye ve Finlandiya'da ana dili öğretmeni yetiştirme sürecinde verilen okul deneyimi ve öğretmenlik uygulaması derslerinin karşılaştırmaktır. Belirtilen amaç doğrultusunda aşağıdaki alt problemler belirlenmiştir:

1. Finlandiya'da ana dili öğretmeni yetiştirme süreci nasıl gerçekleşmektedir?

2. Fince öğretmeni yetiştirme sürecinde verilen "Okul Deneyimi" ve "Öğretmenlik Uygulaması" derslerinin içeriği nasıldır?

3. Türkçe öğretmeni yetiştirme sürecinde verilen "Okul Deneyimi" ve "Öğretmenlik Uygulaması" derslerinin içeriği nasıldır?

\section{Araştırmanın Modeli}

\section{Yöntem}

Bu araştırma nitel durum çalışması olarak planlanmıştır. Yıldııım ve Şimşek'in $(2008$, s. 77$)$ belirtiği üzere "Durum çalışmaları nicel veya nitel yaklaşımla yapılabilir. Her iki yaklaşımda da amaç belirli bir duruma ilişkin sonuçlar ortaya koymaktır. Nitel durum çalışmasının en temel özelliği bir ya da birkaç durumun derinliğine araştırılmasıdır." Nitel araştırmaların gözlem, görüşme ve doküman analizi olmak üzere çeşitli veri toplama yöntemleri vardır.

Araştırmanın veri kaynağı Türkiye ve Finlandiya'daki ana dili öğretmeni yetiştirme programları olduğu için araştırmada doküman analizi yöntemi kullanılmıştır. "Doküman analizi örgütsel, klinik veya program kayıtlarının tam metinlerinin ya da bunlardan yapılan alıntıların, muhtıra ve yazışmaların, resmi yayınlar veya raporların, kişisel günlüklerin, açık uçlu anketlere verilen yazılı cevapların incelenmesini kapsamaktadır." (Patton, 2014, s. 4).

\section{Inceleme Nesnesi}

Araştırmanın inceleme nesnesini Türkiye ve Finlandiya'dan seçilen ana dili öğretmeni yetiştiren kurumlar oluşturmaktadır. Bu kurumlar Gazi Üniversitesi (Türkiye) ve Turku Üniversitesidir (Finlandiya). Turku Üniversitesi, Helsinki Üniversitesiyle birlikte Finlandiya'nın en köklü öğretmen yetiştirme ekollerinden birisi olarak kabul edilmektedir. Kökleri 1640 yılında Turku şehrinde kurulan Kraliyet Akademisine dayanan bu üniversiteler, ülkedeki diğer yükseköğretim kurumlarını etkilemektedir. Türkiye'nin öğretmen yetiştirme amacıyla kurulan eğitim kurumu olan Gazi Üniversitesinin kökleri Cumhuriyet'in ilk yıllarına kadar uzanmaktadır. 1926'da "eğitim enstitüsü" olarak hizmet vermeye başlayan kurum 1982 yılında üniversiteye dönüştürülmüştür. Hâlen ülkenin en seçkin öğretmen yetiştirme kurumlarından birisi olarak hizmet vermeye devam etmektedir.

Finlandiya'nın araştırma kapsamına dâhil edilmesinde PISA araştırmalarının sonuçlarına göre gerek Avrupa Birliği içerisinde gerekse dünyada en verimli eğitim sistemine sahip ülkelerden birisi 
olarak kabul edilmesi etkili olmuştur. ${ }^{1}$ Araştırmada elde edilen yabancı dille oluşturulmuş her türlü kaynak aslına uygun şekilde tercüme ettirilmiştir. ${ }^{2}$

\section{Verilerin Toplanması}

Araştırma kapsamına alınan ülkelerdeki ana dili öğretmeni yetiştirme süreçlerinde sunulan okul deneyimi ve öğretmenlik uygulamaları ile ilgili bilgiler içeren internet siteleri ve resmî belgeler gibi kaynaklardan istifade edilmiştir. Ayrıca araştırma konusuyla ilgili yürürlükte olan mevzuatlar, süreli ve süresiz yayınlar, tezler, makaleler ve tebliğler gibi bilimsel nitelik taşıyan basılı kaynaklar veri toplama maksadıyla incelenmiştir.

\section{Verilerin Analizi}

Araştırmacıların 2014 yılında Finlandiya ziyareti akabinde ulaştıkları çeşitli kaynaklardan topladıkları verilerin güncelliği kontrol edilerek, söz konusu veriler Türkiye'deki ana dili öğretmeni yetiştirme sürecindeki okul deneyimi ve öğretmenlik uygulaması dersleri ile karşılaştırmalı olarak incelenmiştir. Araştırma sürecinde bulguların sıralanmasından sonra, karşılaştırmalı eğitimin kendine özgü analiz yöntemlerine uygun olarak benzerlik ve farklılıklar tespit edilmiştir. Araştırmanın alt problemlerinden hareketle veriler düzenlenmiş, verilerin benzerlik ve farklılıkları tespit edilmiştir. İstatistiksel işlem olarak yüzde hesaplamaları kullanılmıştır.

Verilerin analizi aşamasında safari yönteminden de istifade edilmiştir. Bu yöntem Hentrais tarafından (1995'ten aktaran İnce, Kırtıl ve Özcan, 2008, s.2) "nitel çalışmalarda bir ya da bir grup araştırmacının birden fazla ülkeyi araştırıp bilgi toplaması, sonrasında ise bu bilgileri analiz etmesi" şeklinde tanımlanmıştır.

\section{Bulgular \\ Finlandiya'da Ana Dili Öğretmenlerinin Yetiştirilmesi}

Finlandiya'da 1973-1974 akademik yılından itibaren öğretmen yetiştirme sorumluluğu tamamen üniversitelere bırakılmıştır. Bu uygulamaya bağlı olarak, söz konusu alanda eğitim veren kurumların bazıları kapatılmış bazıları da üniversitelere devredilmiştir. Ülkede üniversitelerin bünyelerinde kurulan eğitim fakülteleri, kırk yılı aşkın süredir öğretmen adaylarına hizmet öncesi eğitim verme sorumluluğunu yürütmektedirler. 2017 yılı itibariyle Finlandiya'da öğretmen yetiştirme hizmeti veren 13 eğitim fakültesi bulunur. Bunlardan en önemlileri ülkenin büyük şehirleri olan Helsinki ve Turku'da hizmet vermektedir.

Finlandiya'da ilköğretimden sonraki aşamalarda (ortaokul ve lise) ders verecek olan branş öğretmenlerinin meslek öncesi eğitimleri "basamaklı sistem" adı verilen bir yapıda planlanmıştır. Söz konusu süreç öncelikle uzmanlık alanıyla ilgili olan bir bölümdeki eğitimle başlar. Adaylar genellikle altı yarıyı süren bu aşamada alan derslerinin ağırlıkta olduğu bir eğitim alırlar. Öğretmenlik yeterliliği elde edebilmek için lisans eğitimini tamamlamış olan adayın, üniversitenin eğitim fakültesinde başlayan ve meslek derslerinin sunulduğu, dört yarıyıl süren eğitimden geçmesi gerekir. Bu eğitim sonunda elde edilen diploma, "yüksek lisans" düzeyindedir. Böylelikle normal şartlarda on yarıyıl süren öğretmenlik eğitimi süreci tamamlanmış olur ve adaya branşında öğretmenlik yapma yetkisi verilir.

\footnotetext{
${ }^{1}$ Finlandiya, 43 ülkenin katıldığı PISA 2000'de okuma alanında birinci, matematik alanında dördüncü ve fen bilgisi alanında üçüncü olmuştur. 41 ülkenin katıldığı PISA 2003'te ise, okuma ve fen bilgisi alanlarında birinci, matematik alanında ikinci durumdadır. 57 ülkenin öğrenci başarısının değerlendirildiği PISA 2006'da Finlandiya, okuma ve matematik alanlarında ikinci olurken, fen bilgisi alanında en başarılı ülke durumundadır. Çoğu OECD üyesi olan 74 ülkenin katılımıyla gerçekleştirilen PISA 2009'da Finlandiya, okuma alanında üçüncü, matematik alanında altıncı ve fen bilgisinde ikinci olmuştur. 65 ülkenin katılımıyla gerçekleştirilen PISA2012 sonuçlarına göre ülke, okuma alanında altıncı, matematik alanında on ikinci, fen bilgisi alanında beşinci olmuştur. Son yapılan 2015 yılındaki PISA araştırmalarında ise Finlandiya'nın yetmiş iki ülke arasında elde ettiği sonuçlar, okuma alanında dördüncülük, matematik alanında on üçüncülük ve fen bilgisi alanında beşinciliktir.

${ }^{2}$ Fince belgelerin Türkçeye tercümeleri Doç. Dr. Atilla JORMA (Makedonya Uluslararası Vizyon Üniversitesi Balkan Araştırmaları Enstitüsü) tarafından gerçekleştirilmiştir.
} 
Finlandiya'da öğretmenlerin meslek yaşantılarına başlamasında yetki ve sorumluluk yerel yönetimlere bırakılmıştır. Bazı belediyelere bağlı okullara atanacak öğretmenleri okul müdürleri ve okul yönetim kurulları seçerken; bazılarında bu seçim belediye seviyesinde yapılır. Öğretmenler seçilirken başvuran öğretmen adayının yükseköğretim mezuniyet derecesi, staj eğitiminde gösterdiği başarı ve öğretme yetenekleri gibi hususlar dikkate alınır (Ekinci ve Öter, 2010, s. 33).

Finlandiya'da Fince öğretmenliği mesleğini elde etmek isteyen adaylar öncelikle diğer branş öğretmenliği eğitimi almak isteyen adaylar gibi ülke genelinde yapılan üniversite sınavına girmek zorundadırlar. Ancak bu sınav sonucunda elde edilen puan, yükseköğretime başlayabilmek için tek başına yeterli değildir. Söz konusu sınavın yapısı Şekil 1'de verilmiştir.

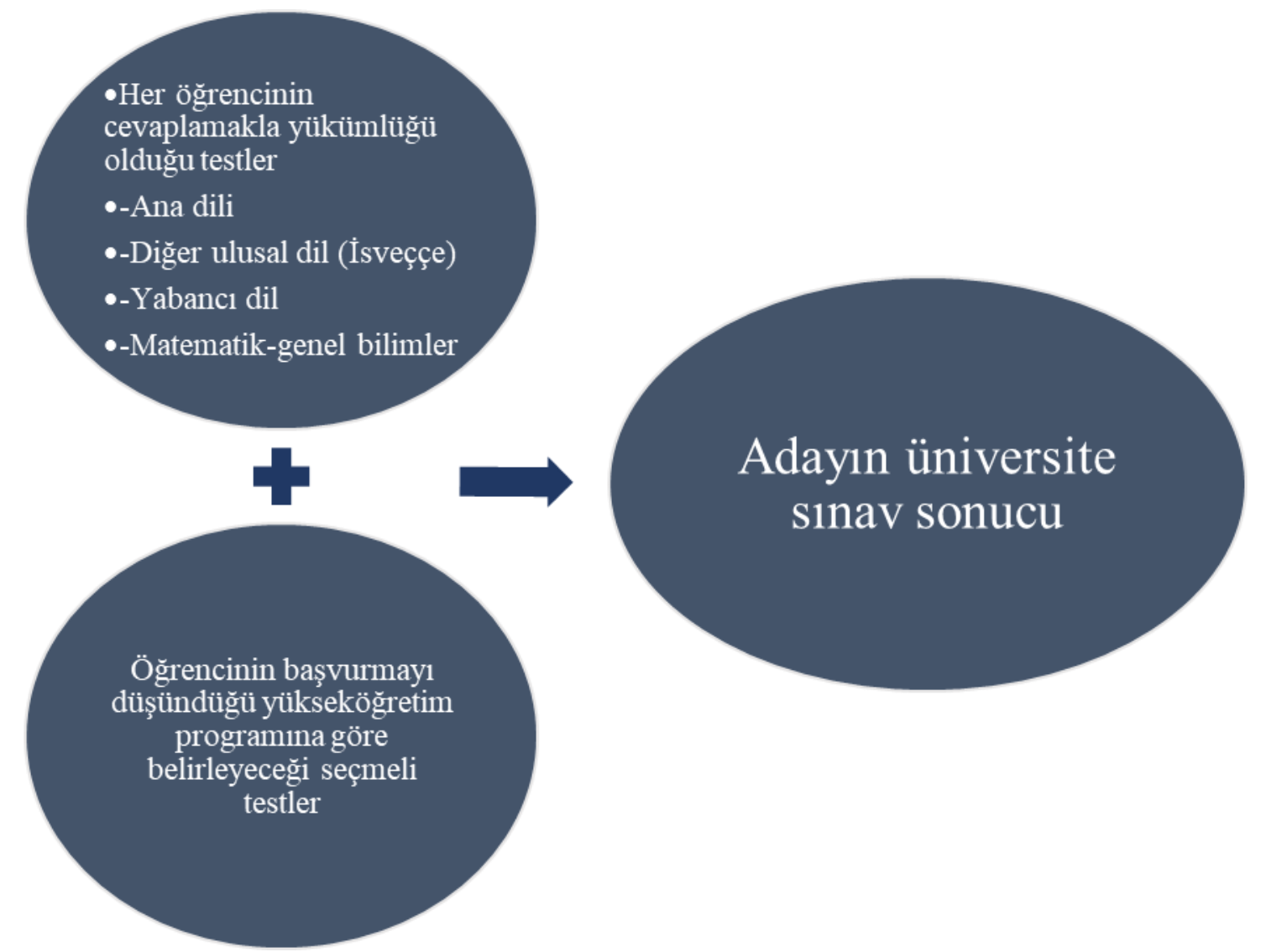

Şekil 1. Finlandiya'da Üniversite Sınavının Genel Yapısı

Üniversite sınavına girmiş olan adaylar lisans eğitimlerini almak için alanlarıyla ilgili bir bölüme başvuruda bulunmalıdırlar. Fince öğretmenliği süreci için bu aşamada genellikle Fin dili, FinUgor dilleri ve Fin edebiyatı gibi bölümler tercih edilse de bu bölümler dışında lisans eğitimi gören adayların öğretmen olmalarını engelleyen bir yönetmelik bulunmamaktadır. Alanla ilgili olmayan bir bölümden lisans diploması alan adaylar da ana dili öğretmenliği yeterliliği veren bir yüksek lisans programına başvuruda bulunabilirler; ancak buradaki gerekli koşul, adayın yeterliliğini jürinin önünde kanıtlamasıdır.

Bölüme yapılan başvurularda üniversite sınav sonuç belgesinin yanı sıra, adayın lise transkripti de kuruma ibraz edilmelidir. Jüriler genellikle her yılın ağustos ayı içerisinde oluşturulur ve kabul edilecek adayları belirleme konusunda tek yetkilidirler. Belgelerin incelenmesi akabinde adayların bir kısmı elenir; kalanlar mülakat için çağırılır. Mülakata çağııılacak aday sayısı jürinin inisiyatifindedir. Mülakatta başarılı olan adaylar fakülteye kayıtlarını yaptırıp lisans eğitimlerine başlarlar.

Eğitim bilimleri alanında ülkenin ve dünyanın en saygın eğitim kurumlarından birisi olarak kabul edilen Turku Üniversitesinden Fince branş öğretmeni yeterliliği almak isteyen adayların lisans eğitimi boyunca seçecekleri dersin AKTS toplamı alınacak isteğe bağlı ders sayısına göre değişiklik 
gösterir. Ancak adaylar Üniversitenin İnsani Bilimler Fakültesi Dil ve Çeviri Çalışmaları Okulu Fin Dili Bölümü gibi alanlarıyla doğrudan ilgili bir departmanda eğitim almaları durumunda 60 AKTS'lik yan dal dersini de seçmek zorundadırlar. Ancak "yan dal" uygulaması ülkedeki üniversitelerin özerklik düzeyine bağlı olarak kurumlar arasında farklıık gösterebilmektedir. Yan dal seçimi konusunda öğrencileri sınırlayan yönetmelikler bulunmamakla birlikte, Turku Üniversitesi Fin Dili Bölümü öğrencilerinin genellikle Fin-Ugor Dilleri, Fin Edebiyatı ve Felsefe gibi yan alanları tercih ettikleri görülmektedir. Öğrenciler gerek ana gerekse yan dal diploması alabilmek için "temel düzey" ve "orta düzey" olarak adlandırılan dersleri lisans öğrenimlerinin sonuna kadar başarıyla tamamlamak zorundadırlar.

Fince öğretmenliği eğitiminin ikinci basamağı olan eğitim fakültesi öğretmen yetiştirme departmanındaki yüksek lisans sürecinde bulunan öğrenciler, alanlarıyla ilgili olan bir lisans programında "ileri düzey dersler" olarak adlandırılan dersleri de almakla yükümlüdür. Bu derslerin bir kısmı öğrencileri eğitimlerinin sonunda savunmaları gereken yüksek lisans tezine hazırlamaya yöneliktir.

Turku Üniversitesinde, Fince öğretmenleri “Insani Bilimler, Matematik ve Doğa Bilimleri Alanları Öğretmenleri için Pedagojik Çalışmalar" isimli yüksek lisans programından yetiştirilirler. Bu programın işleyişinde üç farklı kurum koordineli olarak çalışmaktadır. Bunlar Eğitim Bilimleri Departmanı, Öğretmen Eğitimi Departmanı ve Turku Öğretmenlik Uygulama Okuludur. Eğitim bilimleri dersleri ilgili departman tarafından farklı branş öğretmeni adaylarına ortak şekilde verilirken, alana yönelik konu didaktiği dersleri öğretmen eğitimi departmanından alınır. Toplamda dört adet olan staj dersi ise Öğretmenlik Uygulama Okulunda gerçekleştirilir. Finlandiya'da öğretmen eğitiminin en önemli unsurlarından birisi olarak kabul edilen söz konusu staj dersleri bu araştırmanın odak noktalarından birisidir.

\section{Fince Öğretmeni Yetiştirme Sürecinde “Okul Deneyimi” ve "Öğretmenlik Uygulaması” Dersleri}

Finlandiya eğitim sisteminin en önemli dayanağını öğretmenler oluşturmaktadır. Bu bağlamda öğretmen yetiştirme sistemi Fin eğitim politikalarının başlangıç noktasıdır (Sülün, 2015, s. 16). Jussila ve Saari (2000'den aktaran Sülün, 2015 , s. 16) çalışmalarında, Fin öğretmen yetiştirme programlarının, sistemli akademik yapısı ve yüksek kalitesi nedeniyle, birçok araştırma ve çalışma sonucunda takdir gördüğünü belirtmişlerdir.

Finlandiya'da öğretmenlik eğitimi veren üniversitelerde okul deneyimi ve öğretmenlik uygulamasına yönelik dersler, yükseköğretimin ikinci basamağını oluşturan yüksek lisans eğitimi esnasında verilirler. Ülkedeki üniversitelerin bazılarında bulunmasa da Turku Üniversitesi Fin Dili Bölümü gibi öğretmenlik alt yapısı oluşturmaya yönelik programlarda lisans öğrenimi sırasında öğrencilere "Okul Gözlemi" adında 2 AKTS'lik bir seçmeli ders sunulmaktadır. Tek dönemlik olarak sunulan bu ders, özellikle öğretmenlik mesleğini seçmeyi düşünen öğrenciler tarafından sıklıkla tercih edilmektedir. Bu dersin aday tarafından alınıp alınmadığı eğitim fakültesine başvuru esnasında jüri tarafından göz önünde bulundurulur.

Sözü edilen ders kapsamında gerçekleştirilecek gözlem faaliyetleri, Turku Üniversitesi Öğretmenlik Uygulama Okulunda yapılır. Dersi alan öğrenciler, her hafta girdikleri sınıflardaki gözlemlerini rapor hâline getirirler. Bu raporlardan oluşan bir dosyayı dönem sonunda dersin sorumlu öğretim elemanına sunarlar. Dersten alınacak başarı notu bu dosyadan hareketle belirlenir.

Dünyanın diğer ülkelerinde görülmeyen bir uygulama olarak, Finlandiya'da öğretmen eğitimi veren üniversiteler kendi bünyesinde uygulama okulları bulundurmak zorundadırlar. Öğretmenlik uygulama okullarının iki temel görevi vardır. İlk görev, eğitim fakültelerinin bir alt birimi olarak gelecekteki öğretmenlerin yetiştirilmesine katkıda bulunmak; diğeri ise ilkokuldan lise seviyesine kadar öğrencilere eğitim vermektir. Bu okullarda görev yapan öğretmenlerin tamamına yakını alanlarında doktora eğitimini tamamlamıştır. Öğretmenlik uygulama okullarının diğer bir işlevi ise, yeni eğitim metot ve teknolojilerinin denenmesine ortam hazırlamak ve bu sayede eğitimdeki en yeni değişim ve gelişimlerin takip edilmesine olanak sağlamaktır.

Lisans eğitiminde sadece bir seçmeli dersle sınırlı kalan okul deneyimi ve öğretmenlik uygulamaları, yüksek lisans aşamasının odak noktası durumundadır. Stajın türüne göre değişmekle 
birlikte "Okul Deneyimi" ve "Öğretmenlik Uygulaması" derslerinde adaylar tarafından; öğretmen gözetiminde ders verme, kendi başına ders verme, gözlem yapma, öğrencilerin ev ödevlerine yardım etme, okul kütüphanesinde çalışma ve öğretmenler arasında yapılan toplantılara katılma gibi çeşitli faaliyetler yürütülür.

Staj faaliyetlerinin yürütülmesi için Eğitim Fakültesinden bir öğretim elemanı ile Uygulama Okulunda görev yapan ve "kılavuz öğretmen" olarak adlandırılan bir Fince öğretmeni görevlendirilir. Bir öğretmene düşen öğrenci sayısı istisnai durumlar haricinde beşi geçmez. Turku Üniversitesi öğrencileri için stajlar genellikle haftada on iki saat olarak yapılsa da bu konuda bir yönetmelik bulunmamaktadır.

Stajlarda öğrencilere rakamsal bir not verilmez; sadece "başarılı" ya da "başarısız" ifadeleri ile değerlendirme sonucu açıklanır. Okuldaki kılavuz öğretmen ve sorumlu öğretim elemanı değerlendirme konusunda yetkilidirler. Söz konusu değerlendirme sürecinde öğrencinin tuttuğu aktivite dosyasının sorumlu öğretim elemanına ibrazı zorunludur. Yüksek lisans programının içeriğinde bulunan dört staj dersinin herhangi birinden başarısız olan öğretmen adayı, sonraki dönemde aynı staj dersini tekrar almakla yükümlüdür. İkinci kez aynı staj dersinden başarısız olunması durumunda, öğrenci eğitim fakültesine girişte jüri tarafından yapılan sınava tekrar girmek zorunda kalır.

Turku Üniversitesi Eğitim Fakültesinde Fince öğretmeni olabilmek için eğitim gören öğrenciler, diğer branş öğretmenliklerinde olduğu gibi dört farklı staj dersi görürler. Öğrencilerden bu stajları iki yıllık yüksek lisans eğitim sürecinde bitirmeleri beklenmektedir.

Illk staj "Kılavuzlu Uygulama 1" adıyla programda yer alır. Bu stajın amacı ilgili kaynakta (Turun Yliopisto, 2013, s. 371) "eğitim ve öğretime karşı olumlu bir tutum geliştirme ve öğretmenlik mesleğinin sorumluluklarını anlama; geniş bir yelpazede öğretmenlerinin işinin gereksinimlerini öğrenme" olarak ifade edilir. Ayrıca bu staj; derslere alışma ve egzersiz yapma, planlama, grup ve bireysel çalışma yapabilme, öğretimin denetlenmesi, bir asistan öğretmen gibi davranabilme, okulla ilgili konularda bilgi sahibi olma gibi becerileri geliştirmeyi amaçlar.

Genel olarak öğrencilerin okul ortamına uyum sağlamasını hedefleyen "Kılavuzlu Uygulama I", öğretmen adaylarına uygulama okulunu, okulun eğitim yapısını, öğrenci-öğretmen ilişkilerini gözlemleme imkânı vermesi bakımından önemlidir. Yapılacak olan okul gözlemlerinin öncesinde ve sonrasında uygulama okulu öğretmeni ile staj grubu arasında yapılan değerlendirme ve planlama toplantıları, adayların gözlemleriyle ilgili sorularına cevap bulması hususunda önem arz eder.

133 saat süren bu derste yapılacak olan etkinlikler ve bu etkinlikler için tavsiye edilen süreler şu şekildedir (Turun Yliopisto, 2013, s. 372):

- Oryantasyon dersi (16 saat)

- Kılavuz öğretmen eşliğinde eğitime katılma (31 saat)

- Dersleri takip etme (24-27 saat)

- Öğrencinin verdiği dersler (4-7 saat)

- Rehberlik hizmetleri (20 saat)

- Okul stajı (6 saat)

- Bireysel öğretimin planlanması (60 saat)

Yine bu ders kapsamında, öğretmen adayları için tek ya da çift olarak ders anlatabilecekleri ve 20-30 dakika süren ders anlatımı etkinlikleri de düzenlenebilir (Turun Yliopisto, 2013, s. 372).

Oryantasyon dersleri hem etkileşimi sağlar hem de öğretmen adayını ileride etkin bir parçası hâline geleceği okul ortamı ile tanıştıır. Bu dersler birinci, ikinci ve üçüncü staj dersleri kapsamında ve dönem başlarında yapılırlar. Dersler, eğitim fakültesi ya da uygulama okulunda yapılabilir. Sorumlu öğretim elemanı, kılavuz öğretmen ve stajyerlerin katıldıkları bu derslerde, başlayan dönemdeki staj sürecinin nasıl işleyeceği, hangi faaliyetlerin yürütülmesi gerektiği ve öğretmen adaylarından beklentilerin neler olduğu gibi konular ele alınır. Öğrenciler ilgili süreçle ilgili sorular sorarak yapacakları uygulamalar konusunda detaylı bilgilere sahip olurlar.

"Kılavuz öğretmen eşliğinde öğretime katılma", uygulama dersinin temelini oluşturmaktadır ve uygulama okulundaki sınıf içi etkinlikleri kapsar. Bu etkinlikler için toplamda 31 saatlik çalışma 
önerilir. Sınıf içi uygulamalar, öğrencinin "gözlemci" sıfatıyla notlar alması ve bizzat konu anlatımına katılması olarak kendi içerisinde ikiye ayrılır. Bu alt kollara ne kadar saat zaman ayırılacağı konusunda esneklikler bulunmakla birlikte, bu esnekliği kullanmakla yetkili olan kişiler kılavuz öğretmenlerdir.

"Dersleri takip etme" etkinliğinde, stajyer öğretmen adayları öğretime katılmadan dersleri izler ve gözlemci olarak işlenişe dair notlar tutar. Daha sonra bu notlar rapor hâline getirilerek, dönem sonunda eğitim fakültesi kadrosunda görev yapan sorumlu öğretim elemanına sunulur.

Öğrenci tarafından konu anlatımı, ilk staj dersinde dönem sonuna doğru gerçekleştirilen bir faaliyettir. Sonraki staj derslerinde ise öğretmen adayının hangi tarihte ve hangi konuyu nasıl sunacağı, kılavuz öğretmen ile aday tarafından birlikte kararlaştırılır. Bu noktada öğretmen adayı tarafından yapılmış olan bireysel öğretim planı büyük önem taşır. Kılavuz öğretmen, gerekli gördüğü takdirde bu plan üzerinde birtakım değişikliklere gidebilir.

Finlandiya'da eğitimin her kademesinde rehberlik hizmetlerine üst düzeyde önem verilir. Buna bağlı olarak uygulama derslerini alan stajyerler, öğretmen uygulama okullarının rehberlik servislerinde çalışılar. Burada öğretmen adaylarından servisin işleyişi ve rehberlik uzmanlarının öğrencilerle olan iletişimleri gibi konularda gözlemler yapmaları ve notlar almaları istenir. Bu gözlem notları da dönem sonunda, hazırlanan dosya içerisinde dersin sorumlu öğretim elemanına sunulmalı ve değerlendirme sürecinde dikkate alınmalıdır.

"Okul stajı" öğretmen adaylarının uygulama okulunda dersler dışında yürütülen tüm faaliyetleri gözlemledikleri ve bunlarla ilgili bilgi alarak kendilerini mesleki anlamda geliştirdikleri bir süreçtir. Öğretmen adayı okulun idari işleyişi, yönetim kadrolarının görevleri, kurulların ve zümrelerin teşkilatlanması, veli toplantıları ve benzeri konularda da kendisini geliştirmek zorundadır.

"Bireysel öğretim planlaması", uygulama derslerinde en çok zaman ayırılan faaliyettir. Uygulama dersi alan adaylardan, dönem boyunca kendi fikirlerinin ve yaratıcılıklarının yardımıyla dersin öğretimiyle ilgili planlar yapmaları ve yeni fikirler geliştirerek zenginleştirilmiş öğretim etkinlikleri konusunda çeşitli öneriler sunmaları beklenir. Bu planlar ile önerilerin kılavuz öğretmen ve sorumlu öğretim elemanıyla birlikte değerlendirilmesi; uygulanabilirliği hususunda tartışılması son derece önemlidir. Staj gruplarının sorumlu öğretim elemanıyla birlikte düzenli olarak yaptıkları oryantasyon derslerinde de sözü edilen planların ve önerilerin tartışmaya açılması beklenir. Stajyer öğretmenlerden her şeyin uzmanı olmaları beklenmez, fakat değişik metot ve yaklaşımları denemek konusunda sürekli istek duymalıdırlar. (Turun Yliopisto, 2015, s. 7).

"Kılavuzlu Uygulama II" dersi, "Kılavuzlu Uygulama I" dersinin sonraki aşaması olarak programda yer alır. Ancak bir staj dersini başarılı ile tamamlamak, sonraki ders için ön koşul değildir. Bir dersin öğretmen adayı tarafından seçilebilmesi için önceki uygulama dersinin en az bir kez alınmış olması yeterlidir.

Program kataloğunda "Kılavuzlu Uygulama II" dersinin amacı, "öğretmen adayının, öğrenme sürecini etkileyen faktörlerin ve öğretmenlik işinin bilincine varması, öğrencinin öğrenmesi ve gelişmesinin destekleyicisi olması, öğrencilerin hazırlıklarının ve ders planlarının kontrol edilmesi, değerlendirmenin nasıl yapılacağının öğretilmesi, öğretimle ilgili çeşitli becerilerin çeşitli öğretim durumlarına göre uyarlanabilmesi" (Turun Yliopisto, 2013, s. 378) olarak belirlenmiştir. Bu noktadan hareketle "Kılavuzlu Uygulama II" dersinin, önceki staj dersine nazaran daha geniş bir amaç yelpazesine sahip olduğu görülür.

Illk staj dersi gibi toplamda 133 saatlik bu dersin kapsamındaki çalışmalar ve bu çalışmalara ayrılacak olan saatler şu şekildedir (Turun Yliopisto, 2013, s. 378-379):

- Oryantasyon dersi (6 saat)

- Kılavuz eşliğinde öğretime katılma (30 saat)

- Dersleri takip etme (15-22 saat)

- Öğrencinin verdiği dersler (8-15 saat)

- Rehberlik hizmetleri (20 saat)

- Küçük grup çalışması (4 saat)

- Okul stajı (20 saat)

- Bağımsız öğretim planlaması (53 saat) 
Verilen dağılıma göre, ilk staj dersine oranla oryantasyon derslerinde önemli miktarda azalma görülmektedir. Bu azalmanın sebebi, bu aşamadaki öğretmen adaylarının oryantasyon ihtiyacının ilk staj dersindekine oranla daha düşük olmasıdır. Dersleri takip etme ve bireysel öğretim planlaması saatlerinde düşüş gözlenirken; öğrencinin verdiği dersler, rehberlik hizmetleri ve okul stajında süre artışı olmaktadır. Bu staj dersinde ilk kez öğretmen adaylarına sunulan küçük grup çalışmaları da kılavuz öğretmenin kendi sorumluluğunda bulunan öğrencilere vermiş olduğu görevlerin yerine getirilmesinden ve bu görevlerin sonuçlarının değerlendirilmesinden oluşmaktadır. Bu derslere kılavuz öğretmenin üzerinde sorumlu olduğu stajyerlerin hepsi katılırlar. Bu sayı dört ila yedi arasında değişiklik gösterir.

Güncel katalogda dersin amacı, "Öğretmen adayının kendi öğretmenlik yeteneklerinin farkına varmasını ve gerçekleştirebilmesini sağlamak; öğrenci çeşitliliğinin farkına varma ve ihtiyaçları bu çeşitliliğe göre belirleyebilme becerisini kazandırmak" (Turun Ylipisto, 2013, s.379) olarak yer almaktadır.

133 saatlik ders dâhilindeki çalışmalar ise şu şekilde sıralanır: (Turun Ylipisto, 2013, s.380)

- Oryantasyon dersleri (6 saat)

- Dersleri takip etme (30 saat)

- Dersleri takip etme (15-22 saat)

- Öğrencinin verdiği dersler (8-15 saat)

- Rehberlik hizmetleri (24 saat)

- Küçük grup çalışması (3 saat)

- Okul stajı (20 saat)

- Bağımsız öğretim planlaması (50 saat)

Bu stajın çalışmalar bakımından önceki dersten büyük farklılıklar göstermediği anlaşılmaktadır. En önemli değişiklik ise rehberlik hizmetlerinin gözlemine daha fazla zaman ayırılmasıdır.

2011 yılına kadar öğretmen adaylarının "Kılavuzlu Uygulama III" dersi için gereken uygulamaları Turku Öğretmenlik Uygulama Okulu dışında, Eğitim Bakanlığına bağlı olarak faaliyet gösteren okullarda gerçekleştirmeleri zorunluydu. Bu sayede öğretmen adaylarının, her unsuruyla mükemmelleştirilmiş olan uygulama okullarının yanı sıra diğer okullardaki eğitim ortamlarını tanımaları amaçlanmıştır. Ancak Eğitim Bakanlığı kadrosunda çalışan öğretmenler bu faaliyetler için herhangi bir ek ücret almadıklarından ötürü itirazda bulunmuştur. Buna bağlı olarak Öğretmen Sendikası, kurum dışı staj uygulamalarına son verilmesi konusunda Üniversite yönetimine baskı yapmış ve 2011-2012 akademik yılından itibaren "Kılavuzlu Uygulama III" dersinin öğretmenlik uygulama okulu dışında yapılması uygulamasına son verilmiştir.

Staj eğitiminin son aşaması, "Kılavuzlu Uygulama IV" isimli dersle tamamlanır. Diğer tüm stajlar gibi, "Kılavuzlu Uygulama IV" de Turku Üniversitesi Eğitim Fakültesi bünyesinde hizmet veren Uygulama Okulunda yürütülen ve toplamda 133 saatlik faaliyetleri kapsar.

Dersin amacı "Öğretmen adaylarına okulu tüm unsurlarıyla tanıtmak, adayların okul sisteminin bütününü kavramalarına yardımcı olmak ve onları desteklemek" (Turun Ylipisto, 2013, s. 280) olarak belirlenmiştir. Bu dersin, öğretmen adaylarının kendini geliştirmenin önemini kavrayan, eleştirel düşünebilen, etiğe uygun ve sağlam çözüm önerileri üretebilen bireyler olarak yetişmelerine katkı sağlaması beklenir.

"Kılavuzlu Uygulama IV" dersinin kapsamındaki çalışmalar şunlardır (Turun Ylipisto, 2013, s. 380):

- Uzman dersleri (6 saat)

- Dersleri takip etme (30 saat)

- Dersleri takip etme (15-22 saat)

- Öğrencinin verdiği dersler (8-15 saat)

- Rehberlik hizmetleri (24 saat)

- Küçük grup çalışması (3 saat)

- Okul stajı (20 saat) 
- Bağımsız öğretim planlaması (50 saat)

Yukarıda verilen çalışmaların dağılımı incelendiğinde, son uygulama dersinin bir öncekiyle tek bir unsur haricinde tamamen benzediği görülmektedir. Öğrencilerin bu aşamada ders takibinden çok verdikleri derslere zaman ayırmaları tavsiye edilir (Turun Ylipisto, 2013: 381).

Son uygulama dersinde oryantasyon derslerinin yerine gelen uzman dersleri, uygulama okulundaki kılavuz öğretmen ile stajyerliğini tamamlamak üzere olan öğrencinin birebir olarak gerçekleştirdiği ve dönemlik altı saati kapsayan çalışmalardır. Bu ders saatlerinde stajyerin ders anlatma performansının değerlendirilmesi ve performansa yönelik tavsiyeler ön plan tutulur.

Dört uygulama dersini de başarıyla tamamlayan öğretmen adaylarına, söz konusu uygulamalarda gerçekleştirdiği tüm faaliyetleri gösteren bir belge verilir. Ayrıca uygulama sürecini bitiren öğretmen adaylarından okulun internet sitesi üzerindeki ilgili sanal formlara stajlar hakkında geri bildirimlerde bulunması beklenir. Geri bildirimler, Turku Üniversitesinde branş öğretmenliği eğitimi alan öğrencilerin okul deneyimi ve öğretmenlik uygulamaları çalışmalarını daha nitelikli hâle getirmek için kullanılır.

\section{Türkçe Öğretmeni Yetiştirme Sürecinde Okul Deneyimi ve Öğretmenlik Uygulaması Dersleri}

Dünya üzerindeki birçok ülkede olduğu gibi Türkiye'de de öğretmen yetiştirme sisteminin önemli parçalarından birisi, öğrencilerin bölümlerinde öğrendikleri kuramsal bilgileri okul ortamlarında yapacakları gözlem ve uygulamalarla bütünleştirmelerine olanak sağlayan "Okul Deneyimi" ve "Öğretmenlik Uygulaması" dersleridir. Bu dersler sayesinde ana dili öğretmeni yetiştiren programlar, öğrencilerine öğretim yöntem ve stratejilerini kullanma becerilerini geliştirme olanağı tanımış olurlar. Yine sözü edilen dersler sayesinde, Türkçe öğretmeni adayları lisans eğitimleri boyunca alanlarında edindikleri bilgi ve becerileri gerçek eğitim ortamında verimli ve doğru biçimde kullanma olanağını elde ederler.

Uygun, Ergen ve Öztürk çalışmalarında (2011, s. 390), köklü geleneğe rağmen, Türkiye'de etkin ve verimli bir uygulama eğitiminin olmadığını dile getirerek; uygulama eğitimine yönelik sorunları şu şekilde sıralarlar:

- Programlarda "Okul Deneyimi" ve "Öğretmenlik Uygulaması" gibi dersler olmasına rağmen bu dersler yetersizdir ve etkili bir şekilde hayata geçirilememektedir.

- Uygulama yapılan okullarda öğretmen adayları kendilerini geliştirebilecek ortam bulamamaktadır.

- Uygulama yapılan okullarda görevli personelin uygulama eğitimi konusundaki bilinç ve beceri düzeyi yetersizdir.

- Hizmet öncesi öğretmen eğitimi veren fakülteler ile uygulama yapılan okullar arasında iş birliği ve eşgüdüm eksikliği görülmektedir.

Hizmet öncesi eğitimde öğretmen adaylarının meslekî bilgi ve becerilerini geliştirmelerinde hayati rol oynayan öğretmenlik uygulamalarında hedeflenen başarıya ulaşılamaması, karşılaşılan sorunların çözümüne yönelik araştırmaların yapılmasının gerekli olduğunu ortaya koymaktadır (Uygun, Ergen ve Öztürk, 2011, s. 391).

Öğretmenlik eğitimi veren programlarda öğrenim gören öğrencilerin okullarda gerçekleştirdikleri uygulama çalışmalarının yasal dayanakları şunlardır:

a) Millî Eğitim Temel Kanunu,

b) Millî Eğitim Bakanlığı Teşkilat ve Görevleri Hakkında Kanun

c) Yükseköğretim Kanununun ilgili hükümlerine dayanarak çıkartılan yönetmelik ve yönergeler (Erciyes Üniversitesi Eğitim Fakültesi, 2010a, s. 2).

Öğretmen yetiştiren bölümlerdeki yapılanmaya paralel olarak Yükseköğretim Kurulu ve Millî Eğitim Bakanlığı arasında okul deneyimi ve öğretmenlik uygulaması derslerini düzenlemek amacı ile bir protokol imzalanmış ve konu ile ilgili bir yönerge yayınlanmıştır (Sulak vd. 2009, s. 3).

1739 sayılı Millî Eğitim Temel Yasası, 3797 sayılı MEB Teşkilat ve Görevleri Hakkında Yasa ve 2547 sayılı Yükseköğretim Yasasının ilgili hükümlerine dayanılarak hazırlanan yönergenin amacı şu şekilde belirtilmiştir (MEB, 1998, s. 1): 
“Öğretmen adaylarının, öğretmenlik mesleğine daha iyi hazırlanmalarını, öğrenimleri süresince kazandıkları genel kültür, özel alan eğitimi ve öğretmenlik mesleğiyle ilgili bilgi, beceri, tutum ve alışkanlıklarını gerçek bir eğitim-öğretim ortamı içinde kullanabilme yeterliliği kazanmalarını sağlayacak uygulama çalışmalarına ilişkin usul ve esasları düzenlemek"

Sözü edilen yasal dayanaklara göre okul uygulamalarında görev alan ve sorumluluk üstlenen kurum ve kişiler aralarındaki ilişkiler Şekil 2' de gösterilmiştir.

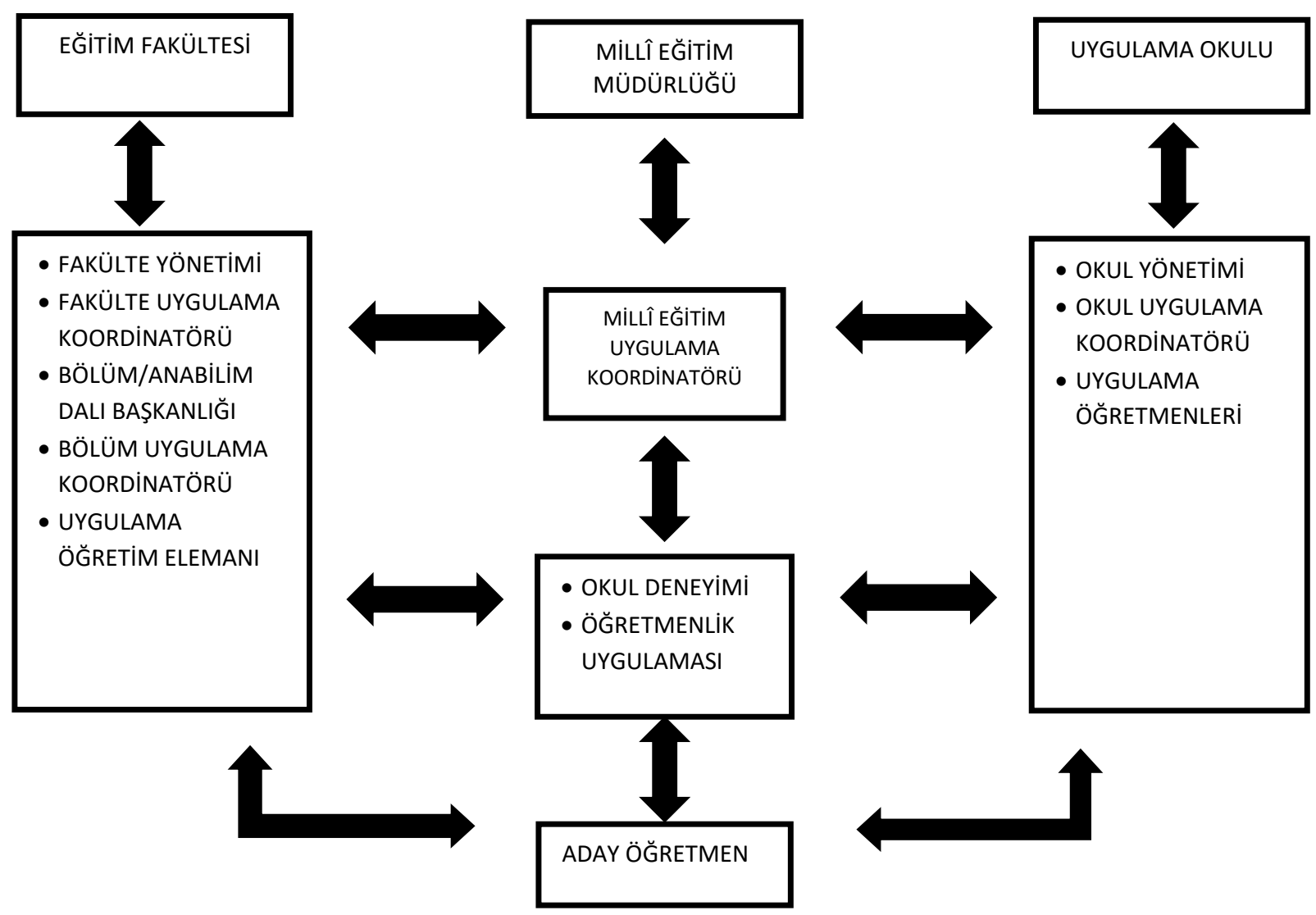

Şekil 2. Türkiye'de Okul Deneyimi ve Öğretmenlik Uygulaması Derslerinde Görev Üstlenen Personel ve Kurumlar (Sulak ve Diğerleri, 2009, s. 4)

Şekil 2'den anlaşılacağı üzere "Okul Deneyimi" ve "Öğretmenlik Uygulaması" derslerinde ana dili öğretmeni adaylarına rehberlik yapmakla görevli olan yetkililer, uygulama öğretim elemanı ve uygulama öğretmenidir. Ayrıca okul ve fakültelerdeki süreci düzenleyen, esaslara uygun şekilde yürütülmesini sağlamakla görevli uygulama koordinatörleri bulunmaktadır. Bunlardan fakülte uygulama koordinatörü, millî eğitim uygulama koordinatörüyle iş birliği yaparak; kadro yapısı ve ulaşım olanakları gibi çeşitli kriterleri göz önünde bulundurarak uygulama okullarını tespit eder. Bölüm uygulama koordinatörü ise okul seçimlerinde fakülte koordinatörüne yardım etmenin yanı sıra; her öğretim elemanının sorumluluğuna verilen öğretmen adaylarının kimler olacağını belirler.

Uygulama öğretim elemanı ise öğretmen adayının okulda gerçekleştireceği etkinlikleri planlama, bu etkinlikler hakkında öğrencilerine önceden bilgi verme, okulda geçirilen süreci düzenli olarak takip etme, öğrencinin performansını değerlendirme ve her konuda rehberlik etme gibi görevleri üstlenir. Ayrıca uygulama öğretim elemanı, her hafta seminer çalışmaları yapıımasını sağlar ve bu sayede öğretmen adayları kendi deneyimlerini birbirleriyle paylaşma olanağı bulurlar. Yine uygulamadan sorumlu öğretim elamanları okullara giderek, adayın durumunu yerinde denetlerler.

Öğretmen adaylarının okul ortamında bulundukları ve deneyim kazandıkları dersler 1950 'li yıllardan bu yana öğretmen yetiştiren kurumların programlarında yer almaktadır. 1998 yılındaki düzenleme ile daha önceki yıllarda sadece iki haftalık stajdan ibaret olan okul uygulamalarına ağırlık verilerek; "Okul Deneyimi I", "Okul Deneyimi II" ve "Öğretmenlik Uygulaması" derslerine öğretmen 
yetiştiren programların içeriğinde yer verilmiştir. Öğretmen yetiştiren programlarda 1998 öncesindeki staj uygulamalarına değinen Şişman (1999, s. 10), sadece tek bir staj dersinden ibaret olan uygulamayı "kısa süreli ve verimsiz" olarak nitelendirir. Türkiye'de "Okul Deneyimi" ve "Öğretmenlik Uygulaması" dersleri konusunda son dönemde gerçekleştirilen diğer önemli düzenleme 2006-2007 akademik yılında gerçekleştirilmiştir. Bu düzenlemeye göre "Okul Deneyimi" ders saatleri azaltılmış; gerekçe olarak uygulama okulları bulmada yaşanan sorunlar gösterilmiştir. Sözü edilen düzenlemeye bağıı olarak, 2016-2017 akademik yılı itibarıyla Türkiye'de Türkçe öğretmenliği de dâhil olmak üzere ilköğretim ikinci kademede görev alacak öğretmenleri yetiştiren tüm bölümlerin programlarında yedinci yarıyılda "Okul Deneyimi" ve Sekizinci Yarıyılında "Öğretmenlik Uygulaması" dersleri bulunur. 2006 yılında yapılan düzenlemeden önce ikinci dönemde verilen "Okul Deneyimi I" ve yedinci dönemde verilen "Okul Deneyimi II" dersleri "Okul Deneyimi" adı altında birleştirilmiştir. Söz konusu düzenleme için öğrencilerin henüz yeterli birikime sahip olmadan okul ortamına girmelerinin olumsuz etkisi ve okulların bulunması sürecinde yaşanan sıkıntılar gerekçe olarak gösterilmiştir. Verimli eğitim sistemlerine sahip ülkelerde, öğretmenlik uygulamalarının ağılığı giderek önem kazanırken, Türkiye'de okul uygulaması derslerinin sayısındaki azalma düşündürücüdür. 2018-2019 akademik yılından itibaren Türkçe öğretmenliği programı içeriği güncellenmiştir. Yeni düzenlemeyle, Türkçe öğretmenliği lisans programının yedinci yarıyılında "Öğretmenlik Uygulaması 1" ve sekizinci yarıyılda bulunan "Öğretmenlik Uygulaması 2" derslerinin haftalık ders saati " 8 " ( 2 teorik + 6 uygulama saati), AKTS değerleri ise ders başına "10" olarak belirlenmiştir. Ancak söz konusu düzenleme Türkçe öğretmenliği programı son sınıflarında 2021-2022 akademik yılından itibaren yer alacaktır.

Öğrencilerin, fakültelerin dışına çıkarak Millî Eğitim Bakanlığına bağlı eğitim kurumlarında çalışmalarını yürüttüğü derslerden ilki olan "Okul Deneyimi" dersi resmi kaynaklarda şu şekilde tanımlanmaktadır (MEB'den aktaran Aytaçlı, 2012, s. 15):

"Okul deneyimi; öğretmen adaylarına okul örgütü ve yönetimi ile okullardaki günlük yaşamı tanıtma, eğitim ortamlarını inceleme, ders dışı etkinliklere katılma, deneyimli öğretmenleri görev başında gözleme, öğrencilerle bireysel ve küçük gruplar hâlinde çalışma ve kısa süreli öğretmenlik deneyimi kazanma olanağı veren bir derstir."

"Okul Deneyimi" dersini alan ana dili öğretmeni adayları, kılavuz öğretmenlerinin denetiminde plan yapma, çeşitli etkinlik ve alıştırmaları düzenleme, öğrenci çalışmalarını değerlendirme gibi etkinlikleri gerçekleştirirler. Bu dersin amaçlarına ulaşılabilmesinin temelinde öğretmen adaylarının gözlem becerileri yatmaktadır. Okul ortamının gözlemi öğretmen adayları için mesleki anlamda elde edecekleri ilk deneyim anlamına gelir.

"Okul Deneyimi" dersi tamamlandığında öğretmen adaylarının şu özellikleri kazanmış olmaları beklenir (Uygun, Ergen ve Öztürk, 2011, s. 397):

- Okulun örgütsel yapısını, işleyişini ve öğretmenliği sistemli bir yaklaşımla tanıma

- Okulun yönetimi ve okuldaki işler ile okulda bulunan kaynaklara ilişkin bilgi sahibi olma

- Sınıf ortamında ve okuldaki diğer etkinlikleri gözlem yoluyla tanıma

Ana dili öğretmeni adayları uygulama öğretim elemanı ve uygulama öğretmeni tarafından belirlenen etkinlikleri kendilerine tanınan süre içerisinde yerine getirmekle yükümlüdür. Dosya hâlinde hazırlanıp uygulama öğretim elemanına teslim edilen dokümanlar, dönem sonunda ders notunun verilmesi aşamasında kullanılır. Ayrıca dersin teorik boyutunu kapsamında fakültelerde gerçekleştirilen seminerlerde öğretmen adayları sorumlu öğretim elemanı ile gözlemleri başta olmak üzere okulla ilgili çeşitli konuları tartışırlar.

"Öğretmenlik Uygulaması" ise öğretmen adayının lisans dönemi boyunca edinmiş olduğu bilgi, beceri, davranış ve kuramsal bilgileri okul ortamı içinde uygulamaya koyup, deneyebilmesi ve mesleğinin gerektirdiği özellikleri kazanabilmesi için hazırlanan bir derstir (Davran, 2006, s. 28). Bu nedenle, tüm diğer branş öğretmenleri gibi ana dili öğretmenlerinin de meslek deneyimlerinin başlangıcı olarak kabul edilecek bu derse yönelik uygulamalar titizlikle yürütülmelidir.

Türkçe öğretmenliği programının sekizinci yarıyılında yer alan "Öğretmenlik Uygulaması" dersi, "Okul Deneyimi" dersinin devamı niteliğindedir ve bu derslerde öğrenilenlerin yanı sıra, kazanılan deneyimlerin de kullanılmasını gerektirmektedir. Bu ders bünyesinde Türkçe ve diğer branşlarda öğretmenlik eğitimi alan adayların, öğretmenlik mesleğini icra etmeleri beklenir. 
Ana dili öğretmeni adayları için öğretmenlik uygulaması dersi, Türkçe derslerini izleme, kendisinden sorumlu branş öğretmeni gözetiminde Türkçe derslerini anlatma, sınav sorusu hazırlama, sınav kâğıdı okuma, nöbet tutma ve idari işlerin gözlemlenmesi gibi öğretmenlik mesleğine ait faaliyetleri kapsar (Erciyes Üniversitesi Eğitim Fakültesi, 2010b, s. 2). Dersin sekiz saatlik haftalık yükünün altı saati okul uygulamalarına, iki saati ise fakültedeki ders ve seminerle ayrılmış durumdadır. Fakültedeki teorik derslerin yürütülmesinde sorumlu olan kişi uygulama öğretim elemanıdır.

Yükseköğretim Kurulu, öğretmenlik uygulaması dersinin amaçlarını şöyle belirlemiştir (1998, s. 28):

- Uygulama okulunda değişik sınıflarda öğretmenlik yaparak öğretmen yeterliliklerini geliştirebilme

- Kendi alanının ders programlarını anlayabilme, ders kitaplarını değerlendirebilme, ölçme ve değerlendirme yapabilme

- Öğretmenlik uygulaması sırasında kazanmış olduğu deneyimleri arkadaşları ve uygulama öğretim elemanı ile paylaşarak kendisini bu yönde geliştirebilme

Bu amaçlara bağlı olarak öğretmen adaylarından öğretmenlik uygulaması dersi ile ilgili olarak beklenen yeterlilikler ve yapılması gereken çalışmalar da şunlardır (YÖK, 1998, s. 28):

- Uygulama saatinin en az üç saatinde sınıfa girerek ders öğretimini gerçekleştirme

- Öteki ders saatlerinde o gün öğretimini yapacağı derslerle ilgili son hazırlıkları yapma

- Tepegöz, fotokopi, çalışma yaprakları ve öteki görsel araçlar gibi ders araçlarını hazırlama

- Verdiği dersle ilgili olarak uygulama öğretmeniyle görüşme

- O gün verdiği dersle ilgili kendi değerlendirmesini yapma

"Öğretmenlik Uygulaması" ve "Okul Deneyimi" derslerinde kullanılan değerlendirme süreci birbirine benzer şekilde yapılandırılmıştır. Dönem boyunca okulda gerçekleştirilen etkinliklere bağlı olarak aday öğretmen tarafından hazırlanan uygulama dosyası dönem sonunda sorumlu öğretim elemanına teslim edilir. Uygulama öğretmenleri her iki derste de sorumlu oldukları öğrencilerin okul ortamında gerçekleştirdikleri çalışmaları aralıklı olarak gözlemleyerek değerlendirirler.

Söz konusu derslerin ara sınav notu uygulama öğretmeninin yukarıda sözü edilen gözlemlerinden hareketle verilir. Genel sınav notu verilirken ise, uygulama öğretim elemanının bizzat okula gelerek izlediği öğretmen adayının başarı düzeyi ve adayın dönem boyunca hazırlamış olduğu etkinlik dosyası göz önüne alınır. Uygulama öğretmeninin adayla ilgili doldurup uygulama öğretim elemanına göndermiş olduğu değerlendirme formunun da notun belirlenmesi konusunda etkisi vardır.

"Okul Deneyimi" dersi 1 saat teorik ve 4 saat uygulama ile haftada 5 saat olarak programda yer alırken; öğretmenlik uygulaması haftada 2 saat teorik ve 6 saat uygulama ile toplamda 8 saatlik bir derstir. İki dersin toplamı haftalık ders saati bakımından Türkçe öğretmenliği toplam ders yükünün yaklaşık olarak \%8'ini oluşturmaktadır. Teorik dersler fakültede bir öğretim elemanı tarafından yürütülür, buna karşılık uygulama derslerinin tamamı okullarda yapılır.

"Okul Deneyimi" Türkçe öğretmenliği programında 8 AKTS kredisine sahip bir ders olarak yer alır. Bu bakımdan 240 AKTS'den oluşan programın \%3,33'lük kısmını oluşturmaktadır. "Öğretmenlik Uygulaması" dersi ise Türkçe eğitimi bölümünde $\% 4,16^{\prime}$ lık oranı ile kredi ağılığı en yüksek olan derslerden birisidir (10 AKTS). Bu yüzden özellikle öğrencilerin sekizinci dönemdeki not ortalamaları üzerinde belirleyici etkiye sahiptir.

"Okul Deneyimi" ve "Öğretmenlik Uygulaması" derslerinin sorunsuz ve program amaçlarına uygun şekilde yürütülebilmesi için üniversiteler ile Millî Eğitim Bakanlığına bağlı okullar arasındaki iş birliğinin önemi aşikârdır. Sözü edilen iş birliğinin amaçları şu şekildedir:

- Planlama, uygulama ve değerlendirmede belirlenen ilkeler çerçevesinde ulusal bir standart oluşturmak.

- Eğitim fakültesi ile uygulama okulu arasındaki iş birliğini geliştirecek bilgi alışverişini sağlamak.

- Eğitim fakültesi ile uygulama okulu arasındaki eğitim-öğretim sürecinde etkileşimi en üst düzeye çıkartmak (YÖK, 1998, s. 5). 
Okul-fakülte iş birliğinin bir diğer boyutu da sözü edilen derslerin değerlendirilmesi aşamasında ortaya çıkar. Uygulama etkinliklerini birlikte planlayıp yürüttükleri için öğretmen adayının öğretmenlik uygulamasındaki performansı, uygulama öğretim elemanı ve uygulama öğretmeni tarafından ayrı ayrı değerlendirilir. Sonrasında ise uygulama öğretmeni gözlem formalarını kullanarak öğretmen adayının ders başarısı ile ilgili kanaatini uygulama öğretim elemanına bildirmesi yine iş birliğinin bir diğer göstergesidir. Türkiye'de sıklıkla gündeme gelen okul uygulamaları derslerin yetersizliği sorununun bir nebze de olsa azaltılabilmesi için her iki eğitim kurumunun da koordineli ve sistemli şekilde çalışmalarını yürütmesi gerekliliği açıktır. Özellikle eğitim alanında yüksek verimliliği olan ülkelerin öğretmen yetiştirme sistemlerine göz atıldı̆ında, Türkiye'deki okul uygulamalarının nicelik bakımından geride olduğu da göz ardı edilemeyecek bir durumdur.

\section{Tartışma ve Sonuç}

Finlandiya öğretmen yetiştirme programlarının en dikkat çekici özelliğinin uygulama ve teorinin bir sentez hâlinde sunulmasıdır. (Ekinci ve Öter, 2010, s. 28). Dört aşamadan oluşan ve toplamda iki akademik yıl süren okul deneyimi ile öğretmenlik uygulamasına dayanan derslerin, öğretmenlerin hizmet öncesi eğitiminde önemli bir yer tutmaktadır. Gerek Finlandiya gerekse eğitimde model olarak kabul edilen Almanya ve İngiltere gibi diğer gelişmiş ülkelerde sözü edilen derslerin branş öğretmeni yetiştiren programların en önemli unsurlarından birisi olarak kabul edildiği görülmektedir. Türkiye'deki öğretmen yetiştirme sistemi de bu çağdaş anlayış gereği, uygulamaya ve okul deneyimine daha fazla ağırlık verilen yeni düzenlemelere ihtiyaç duymaktadır. Finlandiya ve Türkiye'deki okul deneyimi ve öğretmenlik uygulaması derslerinin sayıları, AKTS değerleri ve bu değerlerin programın bütününe oranları Tablo 1'de verilmiştir.

Tablo 1.

Finlandiya ve Türkiye'deki Okul Deneyimi ve Öğretmenlik Uygulaması Derslerinin Sayıları, AKTS Değerleri ve Bu Değerlerin Programın Bütününe Oranları

\begin{tabular}{ccccc}
\hline Ülke & Ders Sayısı & Programdaki Oranı & AKTS Değeri & Programdaki Oranı \\
\hline Finlandiya & 4 & $\% 9,5$ & 20 & $\% 10$ \\
\hline Türkiye & 2 & $\% 3,1$ & 18 & $\% 7,3$ \\
\hline
\end{tabular}

Tablo 1'deki veriler incelendiğinde; "Okul Deneyimi" ve "Öğretmenlik Uygulaması" derslerinin sayısının Finlandiya'da Türkiye'nin iki katı olduğu görülmektedir. Bu derslerin öğretmen eğitimi programının içindeki payları ise Finlandiya'da Türkiye'de olduğunun üç katından fazladır. Söz konusu derslerin AKTS değerleri ve bu değerlerin programdaki oranları bakımından da Finlandiya'daki ana dili öğretmeni yetiştirme süreci Türkiye'nin önünde görülmektedir.

Bir Fince öğretmeni adayı hizmet öncesi eğitim sürecinde toplam 532 saat "Okul Deneyimi" ve "Öğretmenlik Uygulaması" dersi alırken, Türkçe öğretmeni adayları 182 saat ders alarak meslek yaşantılarına başlamaktadır. Finlandiya'da lisans düzeyinde sunulan bir seçmeli ders olan "Okul Gözlemi" de hesaba katııısa ders sayısı, AKTS değeri ve ders saati bakımından iki ülke arasındaki fark daha da artacaktır.

Türkçe ve Fince branş öğretmenlerinin hizmet öncesi eğitimlerindeki staja yönelik dersleri arasındaki önemli bir diğer farklılık, Türkiye'deki üniversitelerde söz konusu derslerin eğitim sürecinin son yılına sıkıştırılmasına karşılık Finlandiya'da söz konusu derslerin mümkün olduğunca geniş bir zaman aralığına yayılmış olmasıdır.

2021-2022 akademik yllından itibaren, gerçekleştirilen son düzenlemenin Türkçe öğretmenliği programının dördüncü sınıflarında uygulanacak olmasına bağlı olarak Tablo 1'de verilen "Okul Deneyimi" ve "Öğretmenlik Uygulaması" derslerinin AKTS değeri ve programdaki oranları artacaktır. Ancak yine de Türkçe öğretmeni yetiştiren yükseköğretim kurumlarındaki öğretmenlik uygulamasına yönelik derslerin program içerisindeki ağırlı̆ının gerek Finlandiya gerekse Almanya, Fransa ve İngiltere gibi Batı Avrupa ülkelerindeki ana dili öğretmeni yetiştirme sistemlerinin gerisinde kalacaktır. Bu durumda Türkiye'de ortaokullar için branş öğretmenleri yetiştiren yükseköğretim 
kurumlarının eğitim süresinin dört yıl, diploma düzeyinin ise "lisans" olmasının etkisi vardır. Verimli eğitim sistemlerine sahip ülkelerde branş öğretmenliği diplomaları genel olarak "yüksek lisans" düzeyinde ve beş yıllık bir eğitim sonucunda elde edilebilmektedir. Türkiye'de de buna benzer bir düzenlemenin hayata geçirilmesi hem ana dili öğretmenlerinin hizmet öncesi eğitimlerinin niteliğini iyileştirecek hem de "Okul Deneyimi" ve "Öğretmenlik Uygulaması" derslerinin niceliğinin artmasına olanak sağlayacaktır. Eğitim süresi uzatılmadan yapılacak düzenlemeler; alan eğitimi, genel kültür ve meslek bilgisi derslerinin sayısında azalmaya neden olacağı için verimli sonuçlar elde edilmesi son derece zordur.

Türkiye'de uygulama okulu bulunması sürecinde yaşanan güçlükler, Finlandiya'dakine benzer şekilde eğitim fakültelerine bağlı uygulama okullarının kurulmasıyla ortadan kaldırılabilir. Bu uygulama öğretmen adaylarının meslek öncesi eğitimlerine fayda sağlamanın yanı sıra; ilkokul, ortaokul ve lise düzeyindeki pek çok öğrencinin okul ihtiyacını karşılayacaktır. Ayrıca kurumda görev yapacak eğitim ve hizmet personelleri için de istihdam oluşturacaktır. Turku Üniversitesi Turku Öğretmenlik Uygulama Okulunda 2015 yılı itibariyle çoğu doktora eğitimini tamamlamış 130 dolayında öğretmen görev yapmakta olup, 250 stajyer ve 900 'ü aşkın öğrenci eğitim hizmeti almaktadır (Turun Ylipisto, 2015, s.3).

Türkiye'de hizmet veren eğitim fakültelerine bağlı uygulama okullarının kurulmasının sağlayacağı bir diğer fayda ise, Türkiye'de Millî Eğitim Bakanlığı ile üniversiteler arasında yaşanan koordinasyon sorununun önüne geçilmesi olacaktır. Son yıllarda pek çok yeni üniversitenin kurulduğu ve yükseköğretime yapılan yatırımların arttığı Türkiye'de, eğitim fakültelerine bağlı uygulama okullarının kurulması kolaylıkla hayata geçirilebilecek bir düzenlemedir. Ancak öğretmen adaylarının, eğitim fakültelerine bağlı uygulama okulları dışında da staj görmeleri, meslek yaşantılarında karşılaşacakları okul ortamlarına alışmaları gerektiğinden ötürü son derece önemlidir. Bu yüzden uygulama okulundaki stajlar mutlaka Bakanlığa bağlı okullarda gerçekleştirilecek uygulamalarla desteklenmelidir.

Çalışmada verilen bilgilerden hareketle, Finlandiya ve Türkiye'deki "Okul Deneyimi" ve "Öğretmenlik Uygulaması" derslerinin görevli personel bakımından oldukça benzer yapıda olduğu anlaşılmaktadır. Her iki ülkede de öğretmen adaylarına uygulamalarda kılavuzluk eden yetkililer uygulama öğretmeni ve sorumlu öğretim elemanıdır.

Uygulama derslerinin genel işleyişi konusunda Türkiye ve Finlandiya arasında büyük farklılıklar görülmemektedir. Öğretmen adaylarının uygulama okullarında gerçekleştirdikleri gözlem ya da ders anlatımına yönelik faaliyetler ve üniversitede sorumlu öğretim elemanı kontrolünde düzenlenen değerlendirme toplantıları her iki ülkede de sürecin odak noktasını oluşturmaktadır. Ancak Fince öğretmeni adaylarının rehberlik servisi ve okul kütüphanesi gibi farklı birimlerde çalışmalar yürütmeleri bunun yanı sıra veli toplantılarına katılmaları, Türkçe öğretmeni adaylarına göre daha çeşitli faaliyetler yürüttüğünü göstermektedir.

Yine öğretmen adaylarının başarısının ölçülmesi ve değerlendirilmesi bakımından da her iki ülkedeki uygulamalar birbirine paralellik arz eder. Ölçme ve değerlendirme sürecinde okuldaki kılavuz öğretmen ile üniversitedeki öğretim elemanının sorumluluk üstlenmeleri her iki ülkede de karşılaşılan bir uygulamadır.

\section{Araştırma ve Yayın Etiği}

Bu çalışmada "Yükseköğretim Kurumları Bilimsel Araştırma ve Yayın Etiği Yönergesi" kapsamında uyulması belirtilen tüm kurallara uyulmuştur. Yönergenin ikinci bölümü olan "Bilimsel Araştırma ve Yayın Etiğine Aykırı Eylemler" başlığı altında belirtilen eylemlerden hiçbiri gerçekleştirilmemiş̧ir.

\section{Yazarların Katkı Oranı}

Çalışmanın 1. yazarı olan Dr. Öğr. Üyesi Celal Can Çakmakcı \%80, 2. yazarı olan Prof. Dr. Necati Demir \%20 oranında çalışmaya katkıda bulunmuştur. 


\section{Çıkar Çatışması}

Bu araştırmada çıkar çatışması teşkil edebilecek herhangi bir durumun bulunmadığı yazarlar tarafından beyan edilmiştir.

\section{Kaynaklar}

Akar, H. (2003). Oluşturmacı öğrenme sürecinin hizmet öncesi öğretmen eğitimi öğrencilerinin erişi, kalıcılık ve tutumuna etkisi, (Yayımlanmamış doktora tezi). Orta Doğu Teknik Üniversitesi Sosyal Bilimler Enstitüsü, Ankara.

Akdemir, A. S. (2013). Türkiye'de öğretmen yetiştirme programlarının tarihçesi ve sorunları. Turkish Studies. 8(12), 15-28.

Aksoy, E. (2013). A.B.D. (New York), Finlandiya, Singapur ve Türkiye'de öğretmen eğitimindeki dönüşümler. (Yayımlanmamış doktora tezi). Ankara Üniversitesi Eğitim Bilimleri Enstitüsü, Ankara.

Ateş, H. ve Burgaz, B. (2014). Türkiye, ABD ve Finlandiya öğretmen yetiştirme sistemlerine ilişkin öğretmen adaylarının görüşleri ve Türkiye'deki sistemin geliştirilmesine ilişkin öneriler. Kastamonu Eğitim Dergisi, 23(4), 1710-1722.

Aytaçlı, B. (2012). Illköğretim matematik öğretmenliği lisans programında yer alan okul deneyimi ve ögretmenlik uygulaması derslerinin değerlendirilmesi. (Yayımlanmamış yüksek lisans tezi). Ege Üniversitesi Sosyal Bilimler Enstitüsü, İzmir.

Aykaç N., Kabaran, H. ve Bilgin H. (2014). Türkiye'de ve bazı Avrupa Birliği ülkelerindeki öğretmen yetiştirme uygulamalarının karşılaştırmalı olarak incelenmesi (Almanya, Finlandiya, Fransa, İngiltere ve Türkiye Örneği). Turkish Studies, 9(3), 279-292.

Azar, A. (2011). Türkiye'deki öğretmen eğitimi üzerine bir söylem: nitelik mi, nicelik mi? Yüksekögrretim ve Bilim Dergisi, 1(1), 36-38.

Bay, E. (2008). Öğretmen eğitiminde yapılandırmacı program uygulamalarının etkinliğinin değerlendirilmesi. (Yayımlanmamış doktora tezi). Atatürk Üniversitesi Sosyal Bilimler Enstitüsü, Erzurum.

Bursalıoğlu, Z. (2012). Okul yönetiminde yeni yapı ve davranış. Ankara: Pegem Akademi.

Çelik, M. A. (2016). Finlandiya ve Türkiye'de zorunlu eğitim sistemlerinin karşılaştırılması. (Yayımlanmamış yüksek lisans tezi). Erzincan Üniversitesi Sosyal Bilimler Enstitüsü. Erzincan.

Davran, E. (2006). İlköğretim kurumlarındaki öğretmenlik uygulamasının öğretmen adaylarııın öğretmenlik yeterliliklerini kazanmaları üzerindeki etkisi (Van ili örneği). (Yayımlanmamış yüksek lisans tezi). Yüzüncü Yıl Üniversitesi Sosyal Bilimler Enstitüsü, Van.

Ekinci, A ve Öter, Ö. M. (2010). Finlandiya'da eğitim ve öğretmen yetiştirme sistemi çalışma ziyareti raporu. Erişim Adresi: duabpo.dicle.edu.tr/oygem/dosya/Finlandiya_Raporu.pdf

Erciyes Üniversitesi Eğitim Fakültesi. (2010a). Okul deneyimi. Erişim Adresi: http://egitim. Erciyes.edu.tr/öğretmenlik/odeneyimi.doc

Erciyes Üniversitesi Eğitim Fakültesi. (2010b). Öğretmenlik uygulaması. Erişim Adresi: http://egitim. Erciyes.edu.tr/öğretmenlik/ouygulama.doc

Ergün, M. (1987). Türkiye'de öğretmen yetiştirme çalışmalarının gelişmesi, Hacettepe Üniversitesi Eğitim fakültesi Dergisi, 2(2), 10-18.

Eşme, i. (1998). Bilgi toplumunda öğretmen yetiştirme. Millî Eğitim Dergisi, 138, 3-6.

Ince, B., Kırtıl, O. ve Özcan, E. (2008, Eylül). Türkiye, Fransa ve Ingiltere'de ana dili öğretmeni yetisstirme modellerinin karşılaştırılması. 17. Ulusal Eğitim Bilimleri Kongresi'nde sunulan bildiri, Sakarya Üniversitesi Eğitim Fakültesi, Sakarya.

Kavcar, C. (2002). Cumhuriyet döneminde dal öğretmeni yetiştirme. Ankara Üniversitesi Eğitim Bilimler Fakültesi Dergisi, 35(1-2), 7-14.

Köse, A. (2016). Okul yöneticilerinin görüşlerine göre aday öğretmen yetiştirme sürecinin değerlendirilmesi. Abant İzet Baysal Üniversitesi Eğitim Fakültesi Dergisi, 16(3), 924-944.

Millî Eğitim Bakanlığı Öğretmen Yetiştirme ve Eğitimi Genel Müdürlüğü. (1998). Millî Eğitim Bakanlığına bağlı eğitim-öğretim kurumlarında yapacakları öğretmenlik uygulamasına ilişkin yönerge. Ankara: Millî Eğitim. 
Okul Deneyimi ve Öğretmenlik Uygulaması Dersleri Açısından Türkiye ve Finlandiya'da Ana Dili Öğretmeni Yetiştirme Süreci

Özkan, S. (2014). Kpss alan bilgisi Türkçe öğretmenliği programı ve özel alan yeterlilikleri kapsamında incelenmesi. (Yayımlanmamış yüksek lisans tezi). Gaziantep Üniversitesi Eğitim Bilimleri Enstitüsü, Gaziantep.

Patton, Q. M. (2014). Nitel araştırma ve değerlendirme yöntemleri. (M. Bütün ve S. B. Demir, Çev. Ed.) Ankara: Pegem Akademi.

Sulak, H. Pilten, Ö. Doğan, A. ve Sulak H. (2009). Okul deneyimi ve öğretmenlik uygulaması. Konya: Eğitim Akademi.

Sülün, E. (2015). Türkiye, Almanya, Finlandiya, Ingiltere ve Kanada müzik öğretmeni yetiştirme sistemlerinin karşılaştırılması. (Yayımlanmamış doktora tezi). Gazi Üniversitesi Eğitim Bilimleri Enstitüsü, Ankara.

Şemşek, i. (2015). Sosyal politika açısından okul öncesi eğitime yönelik uygulamalar: Ingiltere, Finlandiya ve Türkiye örnekleri. (Yayımlanmamış yüksek lisans tezi). Yalova Üniversitesi Sosyal Bilimler Enstitüsü, Yalova.

Şişman, M. (1999). Öğretmenlik mesleğine giriş. Ankara: Pegem Akademi.

Tosunoğlu, M. (2007). Yeni öğretmen değiştirme düzeni ve Türkçe öğretmenliği. Kümbet Altında Dergisi, 3, 18-23.

Turun Yliopisto (2013). Opettajan pedagogiset opinnot, humanistinen ja matemaattisluonnontieteellinen ala. Turku: Turku Yliopiston.

Turun Yliopisto (2015). Build your future careeer with us. Turku: Turku University.

Uygun, S., Ergen, G., ve Öztürk ì. H. (2011). Türkiye, Almanya ve Fransa'da öğretmen eğitimi programlarında uygulama eğitiminin karşılaştırılması. Illköğretim Online. 10(2),389-405.

Üstüner, M. (2004). Geçmişten günümüze Türk eğitim sisteminde öğretmen yetiştirme ve günümüz sorunları. İönü Üniversitesi Eğitim Fakültesi Dergisi. 5(7), 63-82.

Yıldıım, A. ve Şimşek, H. (2008). Sosyal bilimlerde nitel araştırma yöntemleri. Ankara: Seçkin Yayıncilık.

\section{Introduction}

\section{Extended Abstract}

Teaching education consists of subject knowledge, general culture and teaching profession knowledge courses. Education for the teaching profession includes theoretical courses and applications. Theoretical knowledge learned in theoretical courses can be transformed into professional behaviours through practices in the school environment.

In many countries around the world, school experience and teaching practice have two dimensions. The first of these is the studies carried out under the supervision of the responsible lecturers at the university. The second is the applications carried out in the school environment. These two dimensions will provide candidate teachers with the opportunity to get to know their future professions.

While countries are reforming their teacher training processes, they can benefit from the findings of the systems in the countries considered as "models". One of the most important of these countries is Finland.

In this study, school experience and teaching practice lessons in mother tongue teacher training processes in Finland and Turkey are examined. The aim of the paper is to carry out the aforementioned examination and thus to bring concrete suggestions for future regulations on the relevant issue in Turkey.

\section{Method}

This paper was planned as a qualitative case study. Since the data source of the study is mother tongue teacher training programs in Turkey and Finland, document analysis method was used. The study object of the paper consists of institutions that train native language teachers selected from Turkey and Finland. These institutions are Gazi University (Turkey) and Turku University (Finland). 
Sources such as websites and official documents containing information about school experience and teaching practices in mother tongue teacher training processes in the countries included in the study were used. In addition, scientific printed sources such as the legislation in force, periodicals and non-periodical publications, theses, articles and communiqués related to the study subject were examined for data collection. After ranking the findings in the research process, similarities and differences were determined in accordance with the unique analysis methods of comparative education. Based on the sub-problems of the study, the data were arranged, and the similarities and differences of the data were determined.

\section{Result and Discussion}

The school experience and teaching practice lessons that Finnish teacher candidates receive in their pre-service education consist of four stages and last two academic years in total. These practices are the focus of the master's degree phase of the teacher training process. The teacher training system in Turkey needs new regulations that put more emphasis on practice and school experience. In the study, it was found that the number of school experience and teaching practice courses taken by native language teachers in their pre-service education is twice that of Turkey in Finland. Turku University is ahead of the universities in Turkey in terms of the ECTS values of the courses in question and the ratio of these values in the curriculum.

A Finnish teacher candidate takes 532 hours of school experience and teaching practice courses at university. Turkish teacher candidates begin their professional life by taking 182 hours of practical lessons. If the "school observation", which is an elective course offered at the undergraduate level in Finland, is taken into account, the difference between the two countries in terms of the number of courses, ECTS value and course hours will become even wider.

Another difference between the practice courses in the pre-service training of Turkish and Finnish teachers is that these courses are compressed into the last year of the education process in Turkish universities. On the other hand, in Finland, these courses are spread over as wide a period of time as possible.

Starting from the 2021-2022 academic year, the final curriculum arrangement will start to be implemented in the fourth grades of the Turkish language teaching programs. Thus, the ECTS value of practical courses and their ratio in the curriculum will increase. However, the weight of teaching practice courses in higher education institutions that train Turkish teachers will fall behind Turku University. The fact that the education period of higher education institutions that train branch teachers for secondary schools is four years has an effect on the emergence of this situation. In countries with efficient education systems (i.e France, England, Finland), branch teaching diplomas can generally be obtained at the "master's degree" level and after a five-year education. The implementation of a similar arrangement in Turkey will positively affect the quality of pre-service training of mother tongue teachers. In addition, the share of school experience and teaching practice courses in the curriculum can be increased. It is difficult to obtain productive results without extending the training period in arrangements as it will cause a decrease in the number of field education, general culture and vocational knowledge courses.

There are difficulties in the process of finding a practice school in Turkey nowadays. This problem can be eliminated by establishing practice schools affiliated to education faculties, as in Finland. This implementation provides benefits to the pre-vocational education of teacher candidates. In addition, the school needs of many students in the proximity will be met and there will be employment opportunities for education and service personnel. Another benefit of establishing practice schools affiliated to education faculties in Turkey will prevent the coordination problem between the Ministry of National Education and universities in Turkey. However, it is important for pre-service teachers to undergo internships outside of the practice schools affiliated with the faculties of education, as they need to get used to the school environments they will encounter in their professional life. Therefore, internships in the practice school should also be carried out in schools affiliated to the Ministry. 
Okul Deneyimi ve Öğretmenlik Uygulaması Dersleri Açısından Türkiye ve Finlandiya'da Ana Dili Öğretmeni Yetiştirme Süreci

School experience and teaching practice courses in Finland and Turkey are very similar in terms of staff on duty. The demonstrator teacher in the practice and the responsible scholar in the faculty are at the core of the process in both countries. There is no significant difference between the two countries in terms of the general functioning of the practical courses. In terms of measuring and evaluating the success of teacher candidates, the practices in both countries are parallel to each other. 